\title{
OPTIMALISASI PRODUKSI JAGUNG MANIS DENGAN PEMBERIAN PUPUK BERIMBANG ORGANIK DAN ANORGANIK
}

\section{THE OPTIMIZATION PRODUCTION OF SWEET CORN BY THE BALANCED OF ORGANIC AND INORGANIC FERTILIZER}

\author{
Yenni Asbur ${ }^{1 *}$, Yayuk Purwaningrum \\ Program Studi Pascasarjana Fakultas Pertanian USU Medan, 20155 \\ *Corresponding author : yenniasbur@gmail.com
}

\begin{abstract}
ABSTRAK
Produktivitas jagung manis saat ini belum mencapai hasil optimal, sehingga dibperlukan upaya untuk meningkatkannya, salah satunya melalui pemupukan berimbang organik dan anorganik. Penelitian ini bertujuan untuk mengetahui pemupukan berimbang organik dan anorganik yang tepat untuk meningkatkan pertumbuhan dan produksi jagung manis. Penelitian dilaksanakan di kebun percobaan Balai Benih Induk Kabupaten Deli Serdang, Sumatera Utara menggunakan Rancangan Acak Kelompok (RAK) satu Faktor dengan tiga ulangan. Pemupukan berimbang organik dan anorganik yang diberikan terdiri dari 9 taraf, yaitu :100 kg/ha NPK + 5 t/ha pupuk kandang sapi diberikan pada saat tanam, $100 \mathrm{~kg} / \mathrm{ha}$ $\mathrm{NPK}+10 \mathrm{t} / \mathrm{ha}$ pupuk kandang sapi diberikan pada satu minggu sebelum tanam, $100 \mathrm{~kg} / \mathrm{ha}$ $\mathrm{NPK}+15 \mathrm{t} / \mathrm{ha}$ pupuk kandang sapi diberikan pada pada dua minggu sebelum tanam, 200 $\mathrm{kg} / \mathrm{ha} \mathrm{NPK}+5 \mathrm{t} / \mathrm{ha}$ pupuk kandang sapi diberikan pada saat tanam, $200 \mathrm{~kg} / \mathrm{ha} \mathrm{NPK}+10 \mathrm{t} / \mathrm{ha}$ pupuk kandang sapi diberikan satu minggu sebelum tanam, $200 \mathrm{~kg} / \mathrm{ha} \mathrm{NPK}+15 \mathrm{t} / \mathrm{ha}$ pupuk kandang sapi diberikan pada dua minggu sebelum tanam, $300 \mathrm{~kg} / \mathrm{ha} \mathrm{NPK}+5 \mathrm{t} / \mathrm{ha}$ pupuk kandang sapi diberikan pada saat tanam, $300 \mathrm{~kg} / \mathrm{ha}$ NPK $+10 \mathrm{t} / \mathrm{ha}$ pupuk kandang sapi diberikan satu minggu sebelum tanam, dan $300 \mathrm{~kg} \mathrm{NPK}+15 \mathrm{t} / \mathrm{ha}$ pupuk kandang sapi diberikan pada dua minggu sebelum tanam. Hasil penelitian menunjukkan bahwa pemberian pupuk berimbang organik dan anorganik dengan dosis $200 \mathrm{~kg} / \mathrm{ha} \mathrm{NPK}+10 \mathrm{t} / \mathrm{ha}$ pupuk kandang sapi yang diberikan satu minggu sebelum tanaman mampu menghasilkan berat tongkol dan panjang tongkol tertinggi dibandingkan perlakuan lainnya. Berdasarkan pemetaan dua dimensi, produksi jagung manis yang meliputi berat tongkol, diameter tongkol dan panjang tongkol dipengaruhi oleh jumlah daun dibandingkan tinggi tanaman.
\end{abstract}

Keywords : pupuk NPK, pupuk kandang sapi, jagung manis 


\section{PENDAHULUAN}

$\begin{array}{ccr}\text { Jagung } & \text { manis } & \text { (Zea mays } \\ \text { saccharata } & \text { Sturt }) & \text { memiliki }\end{array}$ peranpentingdalampembangunan pertanian nasional maupun regional dengan memberikan keuntungan relatif tinggi apabila dibudidayakan dengan optimal (Sudarsana 2000), karena umur produksi yang lebih singkat, sehingga dapat menguntungkan dari sisi waktu (Palungkun dan Asiani 2004).

Tidak hanya bagian biji, bagian lain dari tanaman jagung manis juga mempunyai nilai ekonomis tinggi, diantaranya batang dan daun muda yang dapat dimanfaatkan sebagai pakan ternak, batang dan daun tua (setelah panen) dimanfaatkan sebagai pupuk hijau atau kompos, batang dan daun kering dimanfaatkan sebagai bahan bakar pengganti kayu bakar, buah jagung muda untuk sayuran dan berbagai macam olahan makanan lainnya (Purwono dan Hartono 2007).

Produksijagungdi Sumatera Utara terus mengalami peningkatan, yaitu 682,042 ton pada tahun 2006 menjadi 804,850 ton pada tahun 2007 , dan menjadi $1,002,863$ ton pada tahun 2008 , dengan pertambahan luas lahansebesar 238,168 ha (BPS 2010). Hasil penelitian Rahmi dan Jumiati (2007), menunjukkan bahwa produktivitas jagung tertinggi pernah mencapai 8.77 ton ha $^{-1}$, sedangkan hasil riil di lapangan potensi hasil jagung manis varietas Super Sweet hanya mencapai 4-6 ton $\mathrm{ha}^{-1}$ (Anonimus 2002).

Belum tercapainya potensi produksi jagung manis tersebudi lapangan dapat disebabkan oleh beberapa faktor, diantaranya belum diterapkannya teknologi budidaya tanaman yang dianjurkan, kondisi iklim yang terkadang kurang menguntungkan serta kesuburan tanah yang terus menurun, sehingga diperlukan upaya untuk menindaklanjuti masalah tersebut.

Salah satu upaya dalam peningkatan produksi jagung manis ini dapat ditempuh dengan pemberian pemupukan berimbang. Hal ini karena pemupukan yang tidak berimbang dapat menyebabkan tanaman tumbuh tidak optimal, karena kekurangan maupun kelebihan pupuk, sehingga akhirnya dapat menyebabkan terjadinya ketidakseimbangan unsure hara dalam tanah, kerusakan sifat tanah, dan pencemaran lingkungan.

Pemupukan berimbang yang diberikan merupakan gabungan antara pupuk anorganik dan organik. Penggabungan pupuk anorganik dan organik ini bertujuan untuk memenuhi kebutuhan nutrisi tanaman jagung manis melalui kandungan unsur hara yang tinggi dan berimbang pada pupuk anorganik dan menjaga kesuburan tanah serta menyediakan unsur hara makro dan mikro untuk tanaman pada pupuk organik. Selain itu, pupuk organik yang diberikan ke dalam tanah akan mempengaruhi sifat fisik, kimia dan biologi tanah, berperan dalam dekomposisi mineral tanah, sumber hara tanaman, pembentuk struktur tanah yang stabil dan mempunyai pengaruh langsung pada pertumbuhan dan perkembangan tanaman (Soepardi 1982; Brady 1990).

Berdasarkan uraian di atas, penelitian ini bertujuan untuk mengetahui pemupukan berimbang organik dan anorganik yang tepat untuk meningkatkan pertumbuhan dan produksi jagung manis.

\section{BAHAN DAN METODE}

Penelitian dilaksanakan di kebun percobaan Balai Benih Induk Kabupaten Deli Serdang, Sumatera Utara dengan ketinggian tempat $\pm 25 \mathrm{~m}$ diatas permukaan laut dengan topografi datar.

Metode yang digunakan dalam penelitian ini adalah Rancangan Acak Kelompok (RAK) satu Faktor dengan tiga ulangan. Pemupukan berimbang organik dan anorganik yang diberikan terdiri dari 9 taraf, yaitu : $100 \mathrm{~kg} / \mathrm{ha} \mathrm{NPK}+5 \mathrm{t} / \mathrm{ha}$ pupuk kandang sapi diberikan pada saat tanam, 
$100 \mathrm{~kg} / \mathrm{ha}$ NPK + 10 t/ha pupuk kandang sapi diberikan pada satu minggu sebelum tanam, $100 \mathrm{~kg} / \mathrm{ha}$ NPK +15 t/ha pupuk kandang sapi diberikan pada pada dua minggu sebelum tanam, $200 \mathrm{~kg} / \mathrm{ha}$ NPK + $5 \mathrm{t} /$ ha pupuk kandang sapi diberikan pada saat tanam, $200 \mathrm{~kg} / \mathrm{ha} \mathrm{NPK}+10 \mathrm{t} / \mathrm{ha}$ pupuk kandang sapi diberikan satu minggu sebelum tanam, $200 \mathrm{~kg} / \mathrm{ha}$ NPK + $15 \mathrm{t} / \mathrm{ha}$ pupuk kandang sapi diberikan pada dua minggu sebelum tanam, $300 \mathrm{~kg} / \mathrm{ha}$ NPK + 5 t/ha pupuk kandang sapi diberikan pada saat tanam, $300 \mathrm{~kg} / \mathrm{ha} \mathrm{NPK}+10 \mathrm{t} / \mathrm{ha}$ pupuk kandang sapi diberikan satu minggu sebelum tanam, dan $300 \mathrm{~kg} \mathrm{NPK}+15 \mathrm{t} / \mathrm{ha}$ pupuk kandang sapi diberikan pada dua minggu sebelum tanam.
Parameter yang diamati meliputi, (1) Komponen vegetatif : tinggi tanaman, dan jumlah daun; dan (2) Komponen produksi : panjang tongkol, diameter tongkol dan berat tongkol.

\section{HASIL DAN PEMBAHASAN}

\section{Komponen Vegetatif}

Data tinggi tanaman dan jumlah daun jagung manis umur 14, 21 dan 30HST (hari setelah tanam) sebagai respon dari pemberian pupuk berimbang organik dan anorganik disajikan pada Tabel 1 dan Tabel 2.

Tabel 1. Data tinggi tanaman jagung manis 14, 21 dan 30HST dengan pemberian pupuk berimbang organik dan anorganik

\begin{tabular}{|c|c|c|c|}
\hline \multirow[t]{2}{*}{ Perlakuan } & \multicolumn{3}{|c|}{ Tinggi Tanaman $(\mathrm{cm})$} \\
\hline & $14 \mathrm{HST}$ & 21HST & 30HST \\
\hline $100 \mathrm{~kg} / \mathrm{ha} \mathrm{NPK}+5 \mathrm{t} / \mathrm{ha}$ pukan, saat tanam & 37.37 & 113.97 & 115.58 \\
\hline $\begin{array}{l}100 \mathrm{~kg} / \mathrm{ha} \mathrm{NPK}+10 \mathrm{t} / \mathrm{ha} \text { pukan, } 1 \text { minggu sebelum } \\
\text { tanam }\end{array}$ & 37.53 & 107.47 & 109.40 \\
\hline $\begin{array}{l}100 \mathrm{~kg} / \mathrm{ha} \mathrm{NPK}+15 \mathrm{t} / \mathrm{ha} \text { pukan, } 2 \text { minggu sebelum } \\
\text { tanam }\end{array}$ & 38.80 & 111.40 & 113.07 \\
\hline $200 \mathrm{~kg} / \mathrm{ha} \mathrm{NPK}+5 \mathrm{t} / \mathrm{ha}$ pukan, saat tanam & 38.53 & 114.97 & 117.27 \\
\hline $\begin{array}{l}200 \mathrm{~kg} / \mathrm{ha} \mathrm{NPK}+10 \mathrm{t} / \mathrm{ha} \text { pukan, } 1 \text { minggu sebelum } \\
\text { tanam }\end{array}$ & 38.13 & 106.13 & 107.23 \\
\hline $\begin{array}{l}200 \mathrm{~kg} / \mathrm{ha} \mathrm{NPK}+15 \mathrm{t} / \mathrm{ha} \text { pukan, } 2 \text { minggu sebelum } \\
\text { tanam }\end{array}$ & 41.27 & 106.43 & 108.00 \\
\hline $300 \mathrm{~kg} / \mathrm{ha} \mathrm{NPK}+5 \mathrm{t} / \mathrm{ha}$ pukan, saat tanam & 38.67 & 116.23 & 117.50 \\
\hline $\begin{array}{l}300 \mathrm{~kg} / \mathrm{ha} \mathrm{NPK}+10 \mathrm{t} / \mathrm{ha} \text { pukan, } 1 \text { minggu sebelum } \\
\text { tanam } \\
300 \mathrm{~kg} / \mathrm{ha} \mathrm{NPK}+15 \mathrm{t} / \mathrm{ha} \text { pukan, } 2 \text { minggu sebelum }\end{array}$ & 36.87 & 106.13 & 107.63 \\
\hline tanam & 38.87 & 106.19 & 107.98 \\
\hline
\end{tabular}

Keterangan: Angka pada kolom yang sama diikuti oleh huruf yang sama tidak berbeda nyata pada $P=0.05$ berdasarkan DMRT

Tabel 1 menunjukkan bahwa pemberian pupuk berimbang organik dan anorganik berpengaruh tidak nyata terhadap tinggi tanaman jagung manis umur 14-30 HST. Hal ini karena tinggi tanaman merupakan karakter genetis dari suatu tanaman. Sitompul dan Guritno (1995) menyatakan bahwa produksi suatu tanaman dipengaruhi oleh faktor genetis, lingkungan dan kultur teknis, dan faktor genetis merupakan faktor yang sulit untuk dirubah.

Jumlah daun pada tanaman merupakan sifat morfologi tanaman yang sangatdipengaruhi oleh faktor genetik. Perbedaan jumlah daun tidak selamanya dapatmemberikan informasi mengenai pertumbuhan tanaman. Hal ini dapat dilihat darihasil analisis terhadap jumlah 
daun (Tabel 2) yang tidak berbeda nyata antara perlakuan pupuk yang diberikan.

Hal ini menunjukkan bahwa, tinggi tanaman dan jumlah daun jagung manis tidak dipengaruhi oleh pemberian pupuk, tetapi lebih dipengaruhi oleh sifat genetis tanaman tersebut, karena tanaman jagung manis sudah mulai memasuki fase akhir pertumbuhan vegetatif. Subekti et al. (2005) menyatakan bahwa pada saat tanaman berumur 30 hari setelah Tabel 2. Data jumlah daun jagung manis berimbang organik dan anorganik perkecambahan, maka tanaman jagung sudah memasukki fase akhir vegetatif. Pada fase ini, kekurangan hara tidak lagi berpengaruh terhadap pertumbuhan vegetatif tanaman, tetapi sangat berpengaruh terhadap pertumbuhan dan perkembangan tongkol, memperlambat munculnya bunga betina (silking), bahkan akan menurunkan jumlah biji dalam satu tongkol karena mengecilnya tongkol (McWilliams et al. 1999; Lee 2007).

14, 21 dan 30 HST dengan pemberian pupuk

\begin{tabular}{|c|c|c|c|}
\hline \multirow[t]{2}{*}{ Perlakuan } & \multicolumn{3}{|c|}{ Jumlah daun (helai) } \\
\hline & $14 \mathrm{HST}$ & 21HST & $30 \mathrm{HST}$ \\
\hline $100 \mathrm{~kg} / \mathrm{ha} \mathrm{NPK}+5 \mathrm{t} / \mathrm{ha}$ pukan, saat tanam & 4.53 & 7.40 & 7.60 \\
\hline $\begin{array}{l}100 \mathrm{~kg} / \mathrm{ha} \mathrm{NPK}+10 \mathrm{t} / \mathrm{ha} \text { pukan, } 1 \text { minggu sebelum } \\
\text { tanam }\end{array}$ & 4.73 & 7.27 & 8.27 \\
\hline $\begin{array}{l}100 \mathrm{~kg} / \mathrm{ha} \mathrm{NPK}+15 \mathrm{t} / \mathrm{ha} \text { pukan, } 2 \text { minggu sebelum } \\
\text { tanam }\end{array}$ & 4.80 & 7.67 & 8.13 \\
\hline $200 \mathrm{~kg} / \mathrm{ha} \mathrm{NPK}+5 \mathrm{t} / \mathrm{ha}$ pukan, saat tanam & 4.73 & 7.53 & 8.13 \\
\hline $\begin{array}{l}200 \mathrm{~kg} / \mathrm{ha} \mathrm{NPK}+10 \mathrm{t} / \mathrm{ha} \text { pukan, } 1 \text { minggu sebelum } \\
\text { tanam }\end{array}$ & 4.53 & 7.20 & 8.33 \\
\hline $\begin{array}{l}200 \mathrm{~kg} / \mathrm{ha} \mathrm{NPK}+15 \mathrm{t} / \mathrm{ha} \text { pukan, } 2 \text { minggu sebelum } \\
\text { tanam }\end{array}$ & 4.87 & 7.67 & 8.67 \\
\hline $300 \mathrm{~kg} / \mathrm{ha} \mathrm{NPK}+5 \mathrm{t} / \mathrm{ha}$ pukan, saat tanam & 4.67 & 7.47 & 8.13 \\
\hline $\begin{array}{l}300 \mathrm{~kg} / \mathrm{ha} \mathrm{NPK}+10 \mathrm{t} / \mathrm{ha} \text { pukan, } 1 \text { minggu sebelum } \\
\text { tanam }\end{array}$ & 4.60 & 7.40 & 8.60 \\
\hline $\begin{array}{l}300 \mathrm{~kg} / \mathrm{ha} \mathrm{NPK}+15 \mathrm{t} / \mathrm{ha} \text { pukan, } 2 \text { minggu sebelum } \\
\text { tanam }\end{array}$ & 4.93 & 7.20 & 8.53 \\
\hline
\end{tabular}

Keterangan: Angka pada kolom yang sama diikuti oleh huruf yang sama tidak berbeda nyata pada $P=0.05$ berdasarkan DMRT

\section{Komponen Produksi}

Pada Tabel 3 terlihat bahwa pemberian pupuk berimbang organik dan anorganik berpengaruh tidak nyata terhadap diameter tongkol, tetapi berpengaruh nyata terhadap panjang dan berat tongkol. Pemberian pupuk $200 \mathrm{~kg} \mathrm{NPK}+10 \mathrm{t} / \mathrm{ha}$ pupuk kandang sapi diberikan satu minggu sebelum tanam memberikan panjang dan berat tongkol tertinggi. Hasil penelitian Nurjaya et al.(2009) juga menunjukkan bahwa pemberian pupuk berimbang anorganik dan organik mampu meningkatkan bobot gabah padi. Hal ini karena penambahan pupuk kandang mampu meningkatkan kemampuan tanah menyimpan air, mengurangi penguapan sehingga membuat kondisi tanah mudah untuk pertumbuhan, perkembangan dan pergerakan akar. Selain itu pupuk kandang juga mampu menyediakan hara makrodan mikro untuk tanaman, meningkatkan daya menahan kation(KTK) dan anion (KTA) sehingga hara tidak mudah hilang dari tanah, serta mampu meningkatkan aktivitas mikroorganisme tanah, seperti organismepenambat $\mathrm{N}$ udara, pelarut $\mathrm{P}$, dan sebagainya (Makarim dan Suhartatik 2006). 
Tabel 3. Data diameter, panjang dan berat tongkol tanaman jagung manis dengan pemberian pupuk berimbang organik dan anorganik

\begin{tabular}{|c|c|c|c|}
\hline \multirow[t]{2}{*}{ Perlakuan } & \multicolumn{3}{|c|}{ Komponen Produksi } \\
\hline & $\begin{array}{c}\text { Diameter } \\
\text { tongkol } \\
(\mathrm{cm})\end{array}$ & $\begin{array}{l}\text { Panjang } \\
\text { tongkol } \\
(\mathrm{cm})\end{array}$ & $\begin{array}{l}\text { Berat tongkol } \\
(\mathrm{t} / \mathrm{ha})\end{array}$ \\
\hline $100 \mathrm{~kg} / \mathrm{ha} \mathrm{NPK}+5$ t/ha pukan, saat tanam & 4.28 & $16.47 \mathrm{c}$ & $8.12 \mathrm{c}$ \\
\hline $\begin{array}{l}100 \mathrm{~kg} / \mathrm{ha} \mathrm{NPK}+10 \mathrm{t} / \mathrm{ha} \text { pukan, } 1 \text { minggu sebelum } \\
\text { tanam } \\
100 \mathrm{~kg} / \mathrm{ha} \mathrm{NPK}+15 \mathrm{t} / \mathrm{ha} \text { pukan, } 2 \mathrm{minggu} \text { sebelum }\end{array}$ & 4.34 & $18.17 a b c$ & $8.82 \mathrm{c}$ \\
\hline tanam & 4.69 & $18.47 \mathrm{abc}$ & $10.64 \mathrm{abc}$ \\
\hline $\begin{array}{l}200 \mathrm{~kg} / \mathrm{ha} \mathrm{NPK}+5 \mathrm{t} / \mathrm{ha} \text { pukan, saat tanam } \\
200 \mathrm{~kg} / \mathrm{ha} \mathrm{NPK}+10 \mathrm{t} / \mathrm{ha} \text { pukan, } 1 \text { minggu sebelum }\end{array}$ & 4.16 & $17.05 \mathrm{bc}$ & $8.46 \mathrm{c}$ \\
\hline $\begin{array}{l}\text { tanam } \\
200 \mathrm{~kg} / \mathrm{ha} \mathrm{NPK}+15 \mathrm{t} / \mathrm{ha} \text { pukan, } 2 \text { minggu sebelum }\end{array}$ & 4.62 & $19.47 \mathrm{a}$ & $12.57 \mathrm{a}$ \\
\hline tanam & 4.61 & $19.20 \mathrm{a}$ & $11.76 \mathrm{ab}$ \\
\hline $300 \mathrm{~kg} / \mathrm{ha} \mathrm{NPK}+5 \mathrm{t} / \mathrm{ha}$ pukan, saat tanam & 4.36 & 17.99abc & $10.06 \mathrm{abc}$ \\
\hline $\begin{array}{l}300 \mathrm{~kg} / \mathrm{ha} \mathrm{NPK}+10 \mathrm{t} / \mathrm{ha} \text { pukan, } 1 \text { minggu sebelum } \\
\text { tanam } \\
300 \mathrm{~kg} / \mathrm{ha} \mathrm{NPK}+15 \mathrm{t} / \mathrm{ha} \text { pukan, } 2 \mathrm{minggu} \text { sebelum }\end{array}$ & 4.27 & 18.20abc & $9.58 b c$ \\
\hline tanam & 4.67 & $18.97 \mathrm{ab}$ & $12.15 \mathrm{ab}$ \\
\hline
\end{tabular}

Pemetaan dua dimensi antar karakter berat tongkol dengan diameter tongkoldan panjang tongkol mengidentifikasi perlakuan terbaik yang menghasilkanberat tongkol dengan diameter tongkol dan pangjang tongkol tertinggi (Gambar1). Garis batas antar kuadran menunjukkan selang kepercayaan $95 \%$.

Pada Gambar 1 terlihat bahwa berdasarkanhasil pemetaan dua dimensi berat tongkoldengan diameter tongkol dan panjang tongkol menunjukkan bahwa bahwa untuk mendapatkan berat tongkol tertinggi dengan diameter tongkol dan panjang tongkol lebih besar, maka tanaman jagung manis sebaiknya diberi pemupukan berimbang organik dan anorganik dengan dosis $200 \mathrm{~kg} / \mathrm{ha}$ $\mathrm{NPK}+10$ t/ha pukan diberikan 1 minggu sebelum tanam; $200 \mathrm{~kg} / \mathrm{ha} \mathrm{NPK}+15 \mathrm{t} / \mathrm{ha}$ pukan diberikan 2 minggu sebelum tanam; dan300 kg/ha NPK+15 t/ha pukan diberikan 2 minggu sebelum tanam

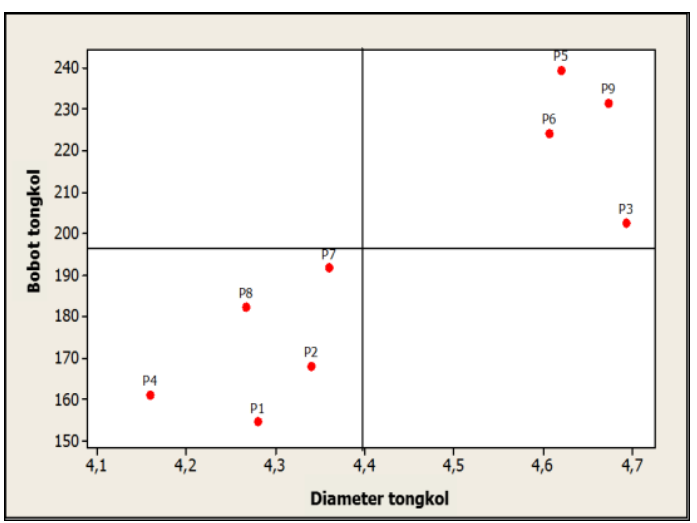

A

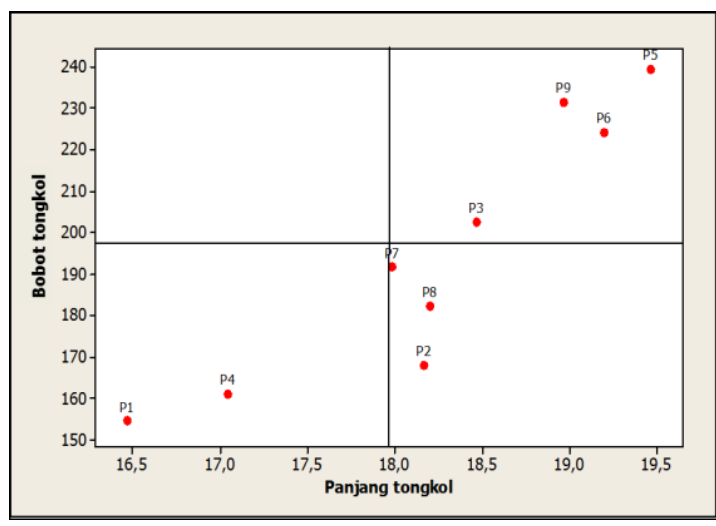

B

Gambar 1. Identifikasi perlakuan terbaik untuk berat tongkol dengan diameter tongkol (A) dan panjang tongkol (B) jagung manis 


\section{HubunganKomponen Produksi dengan Komponen Vegetatif}

Untuk mengetahui komponen produksi dan komponen vegetatif yang mempengaruhi berat tongkol jagung manis, dibuat pemetaan dua dimensi seperti pada Gambar 2. Dari hubungan

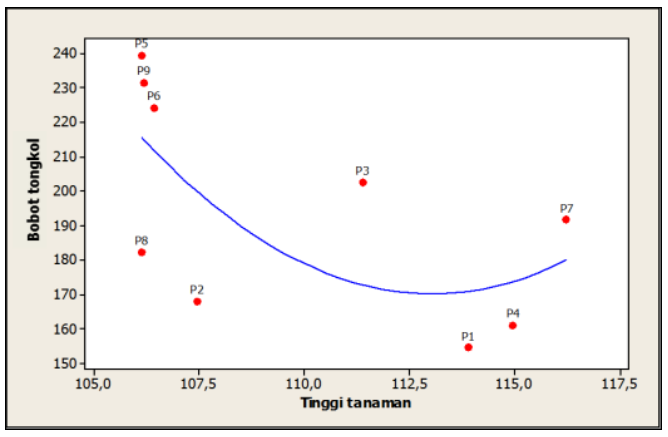

A

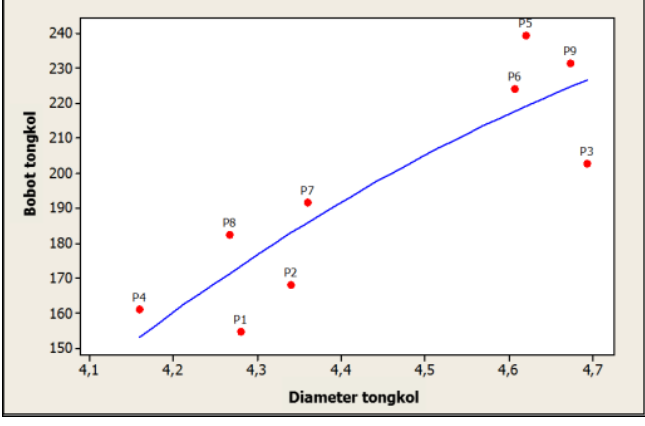

$\mathrm{C}$ yang dibuat menggunakan pemetaan dua dimensi pada Gambar 2 terlihat bahwa berat tongkol dipengaruhi oleh jumlah daun, diameter tongkol dan panjang tongkol, tetapi tidak dipengaruhi oleh tinggi tanaman.

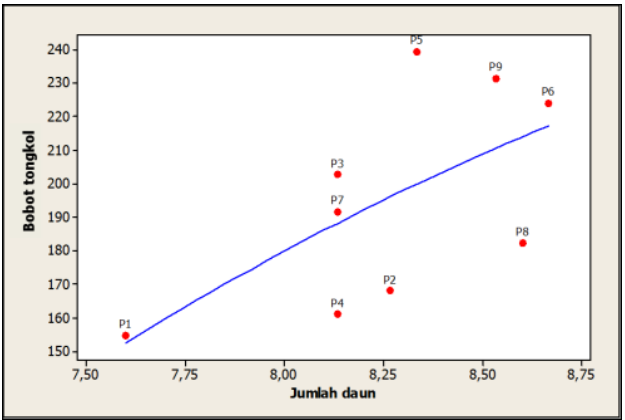

B

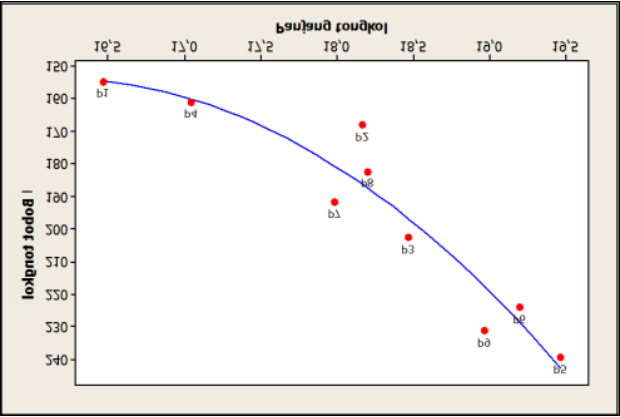

D

Gambar 2 Hubungan berat tongkol jagung manis dengan tinggi tanaman (A), jumlah daun (B), diameter tongkol (C) dan panjang tongkol (D) jagung manis dengan pemberian pupuk berimbang organik dan anorganik

Pada Gambar 2B terlihat peningkatan jumlah daun sampai jumlah tertentu akan meningkatkan berat tongkol jagung manis. Demikian pula pada

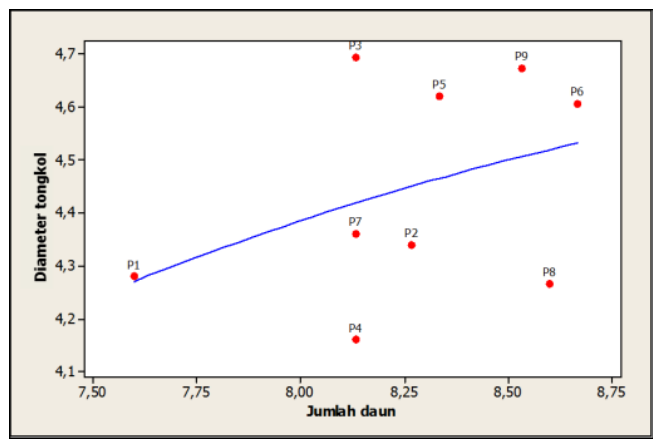

A
Gambar 2C dan 2D menunjukkan bahwa peningkatan diameter dan panjang tongkol sampai ukuran tertentu akan meningkatkan berat tongkol jagung manis.

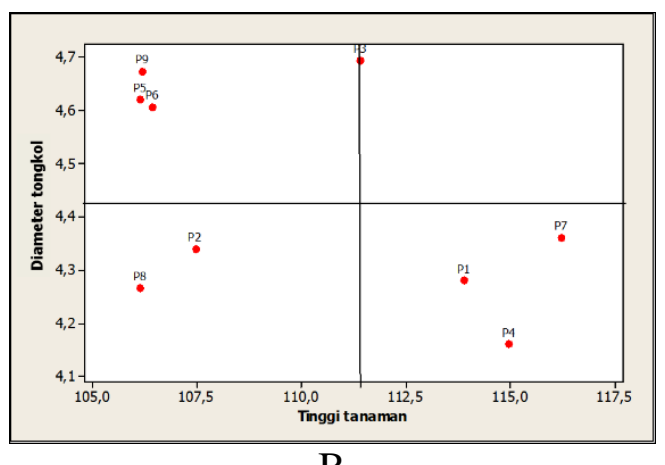

Gambar 3 Hubungan diameter tongkol jagung manis dengan tinggi tanaman (A), dan jumlah daun (B) jagung manis dengan pemberian pupuk berimbang organik dan anorganik 
Hubungan antara berat tongkol jagung manis dengan jumlah daun, diameter tongkol dan panjang tongkol jagung manis menunjukkan bahwa peningkatan jumlah daun, diameter dan panjang tongkol akan diikuti oleh peningkatan berat tongkol, tetapi apabila peningkatan jumlah daun, diameter dan panjang tongkol sudah sampai pada nilai optimum, maka peningkatan jumlah daun, diameter dan panjang tongkol akan menurunkan bobot tongkol, karena pada saat jumlah daun, diameter dan panjang tongkol sampai pada nilai optimum, maka bobot tongkol akan maksimum.

Diameter tongkol jagung manis juga lebih dipengaruhi oleh jumlah daun dibandingkan tinggi tanaman jagung manis (Gambar 3A dan 3B). Gambar 3A menunjukkan bahwa semakin banyak jumlah daun jagung manis sampai jumlah tertentu akan meningkatkan ukuran diameter jagung manis.

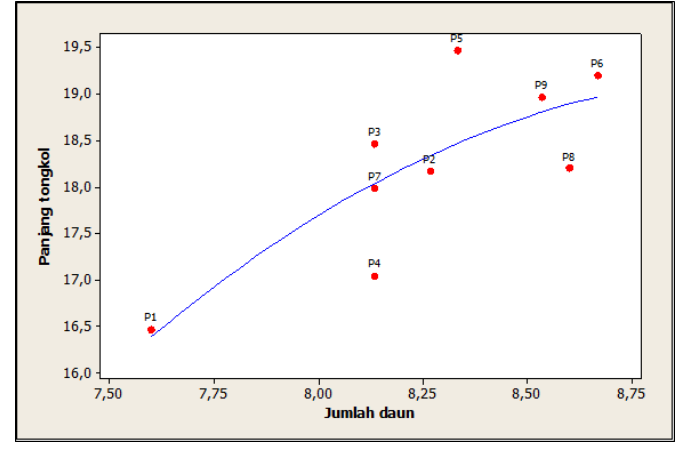

A

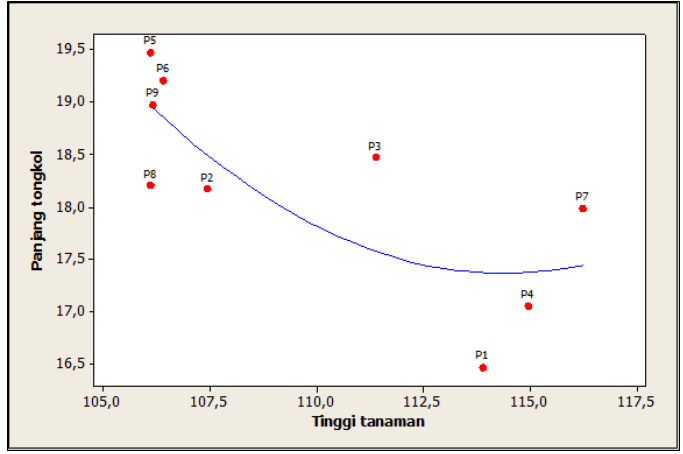

B

Gambar 4 Hubungan panjang tongkol jagung manis dengan tinggi tanaman (A), dan jumlah daun (B) jagung manis dengan pemberian pupuk berimbang organik dan anorganik

Demikian pula panjang tongkol jagung manis lebih dipengaruhi oleh jumlah daun jagung manis (Gambar 4A) dibandingkan tinggi tanaman jagung manis (Gambar 4B). Daun merupakan variabel yang sangat penting kaitannya dengan pertumbuhan dan produksi tanaman secara keseluruhan, karena daun merupakan organ utama tempat terjadinya fotosisntesis yang selanjutnya akan menghasilkan fotosintat untuk kebutuhan organ-organ tanaman lainnya (Gardner et al. 1991).

Hasil penelitian Hasanuddin et al.
(2000) pada tanaman kedelai,

\section{SIMPULAN}

Pemberian pupuk berimbang organik dan anorganik dengan dosis 100 menunjukkan bahwa varietas kedelai yang mempunyai jumlah daun lebih banyak maka akan meningkatkan nilai total luas daun, sehingga akan meningkat pula bobot bijidalam satuan waktu tertentu (Brown 1984 ; Hasanuddin 1999).Dijelaskan olehGesch et al. (2002), bahwa luas daun optimum memberikan permukaan daun yang lebih luas sebagai tempat terjadinya fotosintesis, sehingga penetrasi sinar matahari lebih optimum dan hasil fotosintesis yang diperoleh lebih maksimal.

$\mathrm{kg} / \mathrm{ha} \mathrm{NPK}+15$ t/ha pukan diberikan 2 minggu sebelum tanam; $200 \mathrm{~kg} / \mathrm{ha}$ $\mathrm{NPK}+10$ t/ha pukan diberikan 1 minggu sebelum tanam; $200 \mathrm{~kg} / \mathrm{ha} \mathrm{NPK}+15 \mathrm{t} / \mathrm{ha}$ 
pukan diberikan 2 minggu sebelum tanam; dan $300 \mathrm{~kg} / \mathrm{ha} \mathrm{NPK}+15$ t/ha pukan diberikan 2 minggu sebelum tanam mampu menghasilkan berat tongkol dan diameter tongkol tertinggi dibandingkan perlakuan lainnya.

Berdasarkan pemetaan dua dimensi, produksi jagung manis yang meliputi berat tongkol, diameter tongkol dan panjang tongkol lebih dipengaruhi oleh jumlah daun dibandingkan tinggi tanaman.

\section{DAFTAR PUSTAKA}

Anonimous. 2002. Sweet Corn dan Baby Corn. Penebar Swadaya, Jakarta.

Badan Pusat Statistik. 2010. Produksi dan impor Jagung Manis.www.bps.go.id. Diakses 05Desember 2013.

Brady M. 1990. The Nature and Properties of Soils. $10^{\text {th }}$ ed. Macmillan Publ. Company. New York.

Brown RH. 1984. Growth of the green plant. 153-174p. In : M. B. Tesar (ed.) Physiological Basis of Crop Growth and Development. ASA, CSSA. Madison-Wisconsin.

Gardner PF, Pearce RB dan Mitchell RL. 1991. Fisiologi Tanaman Budidaya. UI-Press. Jakarta. 428 hal.

Gesch RW, ForcellaF, Barbour N, Phillips B, andVoorheees WB. 2002. Yield and growth response of Chupea to sowing date. Crop Sci. 42 : 19591965.

Hasanuddin, Darusman dan Syamsuddin. 1999. Analisis Pertumbuhan Tanaman Kedelai (Glycine max L.) Pada Berbagai Varietas, Jarak Tanam, dan Pemupukan. Agrista 3(1) : 55-58p.

Hasanuddin, Jauharlina dan Gina Erida. 2000. Analisis Pertumbuhan Tanaman Kedelai (Glycine max L. Merril) Pada Berbagai Varietas, Populasi Tanaman dan Teknik
Pengendalian Gulma. Agrista 4(1) : 91-98p.

Lee C. 2007. Corn growth and development. www.uky.edu/ag/grain crops. [20 Januari 2015].

McWilliams DA, Berglund DR, and Endres GJ. 1999. Corn growth and management quick guide.www.ag.ndsu.edu. [20 Januari 2015].

Makarim AK, dan ESuhartatik. 2006. Budi daya padi dengan masukan in situ menujuperpadian masa depan. Iptek Tanaman Pangan, No. 1.

Nurjaya, Adamy I, dan Sri R. 2009. Neraca hara dan produktivitas pada usahatani padi sistem konvensional, PTT, SRI, dan semi organik di lahan sawah irigasi dengan tingkat kesuburan rendah.Prosiding dan Lokakarya Nasional Inovasi Sumberdaya Lahan. Buku II: Teknologi Konservasi, Pemupukan, dan Biologi Tanah. Balai Besar Penelitian dan Pengembangan Sumberdaya Lahan Pertanian. Badan Penelitian dan Pengembangan Pertanian, Kementerian Pertanian. www.balittanah.litbang.deptan.go.i d. Diakses 28 November 2013.

Palungkun R, dan. Asiani B 2004. Sweet Corn-Baby Corn : Peluang Bisnis, Pembudidayaan dan Penanganan Pasca Panen. Penebar Swadaya. Jakarta, 79 hal.

Purwono M, dan Hartono R. 2007. Bertanam Jagung Manis. Penebar Swadaya. Bogor. 68 hal.

Rahmi A, dan Jumiati. 2007. Pengaruh konsentrasi dan waktu penyemprotan pupuk organik cair super ACI terhadap pertumbuhan dan hasil jagung manis. Agritrop, 26 (3) : 105-109.

Sitompul SM, Guritno B. 1995. Analisis Pertumbuhan

Tanaman. 
Yogyakarta: Gadjah Mada

University Press.

Soepardi G. 1982. Sifat dan Ciri Tanah.

Departemen Ilmu-Ilmu Tanah.

Fakultas Pertanian Institut

Pertanian Bogor. Bogor.

Subekti NA, Syafruddin, Efendi R, dan Sunarti S. 2015. Morfologi tanaman dan fase pertumbuhan jagung. Jagung: Teknik Produksi dan Pengembangan : 16-28. http://balitsereal.litbang.pertanian.g o.id. [21 Maret 2015].

Sudarsana K. 2000. Pengaruh EffectiveMicroorganism-4 (EM-4) dan Kompos pada Produksi Jagung Manis (Zea mays saccharata) pada Tanah Entisols. www.unmul.ac.id [2 Februari 2015]. 